\title{
African Religious Healing Practices: A Case Study of the Dagomba Ethnic Group in Northern Ghana
}

\author{
Abdulai Salifu Izudeen \\ Social Science Department \\ Bagabaga College of Education, P. O. Box 35 ER \\ Tamale Ghana, West Africa
}

\begin{abstract}
Many people in Ghana have some negative perception about indigenous African Healing. They think that any spiritual activity associated with African practices is devilish. Hypocritically, the same people seek assistance from these sources in times of serious illness. The academic works on this subject are mostly anthropological, which seem to generalize the African situation. However, what is less well known is that the Dagomba healing practices are not widely documented. This paper seeks to do two things, first, who are the Dagomba in Ghana and second, what is the African traditional worldview of the Dagomba people in relation to their religious belief. The outline provided here would give a better impetus for one to precisely highlight the healing process of the people. This paper also examines the nature of Dagomba religious healing practices, as have been observed over the years. Some recent contacts with elders and the practitioners in the form of oral interview are also brought to bear. The paper asserts that the Dagomba healing practices are intertwined with their everyday life style. It further asserts the need for complementary health practices on both indigenous and modern health.
\end{abstract}

\section{Introduction}

Indigenous African health practices are increasingly gaining research currency especially in developing countries (Bour, 2013). These discussions usually centre on; first, tracing the causes and treatment of diseases in general (Clements 1952). Second, describing the role of healers and their relationship with clients (Mbiti, 1969 and Lehman, 2001) and finally, the prospects and set backs of African health practice (Anfom, 1986). Nevertheless, it seems that the religious aspect of the healing is not emphasized in the various academic discourses. This is why the article has a great interest in the religious aspect of the healing practice of the Dagomba people in Northern Ghana, focusing particularly on the nature and how the indigenous African Traditional Religion influence the healing process and its impact on the people. It is prudent to begin with working definition of the concept "African Healing" and explains its dynamics in the form of literature review. Again, the article tries to find out from the life style of the people, whether the African religion indeed has influence over the healing practices, counting on the long-standing observation of the Dagomba since childhood. Finally, the way-forward in dealing with healing practice of the people is discussed. The article therefore intends to use Dagomba to establish a sustainable practice of indigenous medicine in Ghana without any malice. It postulates that the healing practices in the society determine the general well-being of the society.

\section{African Traditional Healing as a Concept}

Traditional African Healing or medicine is a sum total of all knowledge and practices, whether explicable or not used in diagnosis, prevention and elimination of physical, mental or societal imbalance, and relying exclusively on practical experience and observation handed down from generation to generation, whether verbally or in writing (WHO, 2002). The WHO report clarifies issues by adding that, when traditional healing medicine is adopted by other population outside indigenous culture, it is often termed complementary or alternative medicine. Weiman is a health researcher who supports this definition by opining that the African Traditional Healing is intertwined with cultural and religious beliefs, and holistic in nature. It does not focus only on the physical condition, but also on the psychological, spiritual and social aspects of individuals, families and communities. Weiman continues to argue that, out of two of every four cases treated by traditional healers rated themselves cured, suggesting that the holistic approach is subjective improvement. Cook and Hillenbrand also buttress the point that, traditional practitioners are well known for treating patients holistically. 
According to them, the traditional healers usually attempt to reconnect the social and emotional equilibrium of patients based on community rules and relationships (Cook, 2009 and Hillenbrand, 2006). In all these, "The draft strategic plan document for traditional health care in Ghana." Sums up the definition of traditional medicine as follows:

For the purpose of clarification, traditional medicine shall refer to the beliefs, ideas and practices of a person recognized by community in which he or she lives as competent and qualified to provide health care using natural occurring substances. This can also include other methods based on the social, cultural and religious background as well as on the knowledge, attitudes and beliefs that are prevalent in the community regarding physical, mental and social well-being and the causation of disease and disability

Deducing from these definitions, one thing stands clearly; that is, traditional healing targets the total well-being of the client and the healer is often a community member who understands the people and their environment.

\section{The Dynamics of African Traditional Healing}

Hahn (1995) thinks that defining African healing seldom varies but its practice is varied and must be put in perspectives. Just as humans have always suffered from disease, so too have we always, responded to it, seeking ways to reduce its debilitating nature, or we hope to burnish it completely. All human societies have belief systems and practices that people turn to in order to identify disease and affect a cure.

Explanations and cures of illness may be either natural or supernatural. One of the healer`s most important task is to distinguish between different types of causation and to understand the relationship between them, especially because different types of causal explanation may be involved in different points during the process of diagnosis and treatment or may characteristically demand different treatment (Joyce and Thomas 1982). So, it is for Mascie Taylor (1993) to enumerate five causes of diseases to confirm the divisions of Joyce and Thomas. He calls it the supernatural causes; break of taboo, intrusion of a disease object, intrusion of a disease causing spirit and loss of soul. Obviously, some of these causes may not be applicable in most societies. In this case, Bichman (1970) disagrees slightly and argues that types of cures sought are based not only on the cause but also on the severity of illness in terms of level of pain and difficulty of curing. He further makes a claim that treatment based on cause severity varies greatly. Indeed, illness may be viewed as being natural; but it may be exacerbated by supernatural forces such as witchcraft and spells (Edwar, 1980).

The healer is the centre point of African traditional healing (Shorter, 1980). Mbiti prefers to call the healer as "Medicine-Man". The duties of medicine-man are many and varied. It is the medicine man's duty to combat witchcraft and magic by preventing their action. On a whole the medicine man gives much attention and time to the patient which enables him to penetrate deep into the psychological state of patient. That is, prosperity and good future, as well as ritual cleansing when harm or impurities have been contracted (Mbiti; 1969). Again, the medicine man offers a prayer as he treats the sick indicating that God is rather the ultimate healer. They believe that they do not wield final power for healing the sick, but they only use the power, skills and knowledge given to them by God. Some perform sacrifices or religious rituals in connection with their work. In prayer they confess their humility that, "we do not know how to pray to God in ways better than those he already uses" (Mbiti 1974, p38).

The role of the diviner is equally paramount in the healing practice of the African people. They are the agents of unveiling mysteries of human life. This is done through the use of mediums, oracles, being possesses, divination objects, common sense, intuitive knowledge and insight. They serve as counsellors, judges, comforters, suppliers of insurance and confidence during people's cries and most importantly diagnose illness and assist the healer to know which remedy to apply (Mbiti, 1969). For instance, in South Africa the diviner (Sangoma) is the most senior of the traditional healers, who is highly respected for her mystical powers (WHO, 2002). The dynamism here is further clarified in the WHO report to mean that, a diviner may or may not have knowledge of medical herbs but they still can provide medication for the specific cases they have diagnosed.

Finally, when the diagnostic process seeks answers to the question of how the disease originated (immediate causes), what caused the disease (efficient cause) and why it has affected this particular person at this point in time (ultimate cause), then the therapeutic process and method used by the healer kick start (WHO strategic report, 2002-2005). The method include; psychosocial counseling, simple surgical methods (in the form of the bloodletting and cupping) and rituals. These are further classified into other categories such as preventive, curative (treatment for ailments), and medication to destroy power in others (WHO, 2002). 
To prevent is to protect the patient from possible affliction by performing ceremonial acts or wearing totemic objects. Curative treatment mostly involves preparation of powders, poultices, ointments and so on, either hot or cold. Rituals sometimes too are performed to cast out spells from individuals who are been bewitched. This take the form of induction of vomiting, enemas, blood-letting and whistling or elaborate rituals (sacrifices). Rituals play an important role because in such cases Africans believe that if the ancestors with draw their protection and gift of good fortune, the descendant is left vulnerable to all sorts of misfortunes and diseases. The rituals reduce patient's anxiety and serve to restore balance and harmony in terms of beliefs and values (Mbiti, 1969, WHO, 2002).

\section{The Dagomba people}

The Dagombas are ethnic group of the kingdom of Dagbon (Northern Ghana) and they number about 825,735 (2000 census report). They speak the Dagbani language which belongs to the Mole-Dagbani sub-group of Gur language. The homeland of Dagomba is called Dagbon and it covers about 20,000 km area. Dagombas are one of the ethnic groups with sophisticated Oral traditions woven around drums and other musical instruments. Thus, most of its history, until quite recently, has been passed down via oral tradition with drummers as professional griots. The Dagomba culture is heavily influenced by Islam, nonetheless, all the African traditions still are practiced. The area has up to seven administrative districts in this present day Ghana. They are; Tamale metropolis, Tolon/Kumbungu, Savelgu/Nantong, Yendi, Gushegu/Kariga, Zabzugu and Tatale. The overlord of the Dagbon traditional kingdom is the Ya-Na, whose court or administrative capital is Yendi (Mahama, 2004 and "Dagomba in Ghana," retrieved 5 ${ }^{\text {th }}$ July, 2015 p://Joshusproject.net/people/people/groups(11470/GH).

\section{Religious Beliefs of the Dagomba}

The traditional African worldview of the Dagomba is perceived in various ways they believe in the Supreme Being; thus, everything in life according to them is traced to God. Naawuni (God) is the creator; he delegates powers and functions to host of spirits, who are thus an indispensable link with Him. Nawuni "belong" to all mankind, manifesting in the fact that, "the Dagombas do not know where Nawuni lives or the language he speaks". The other gods (Wuna-plural, singular is Wuni) take peoples prayers to Naawuni, just as approaches the chief through the linguist or some other intermediary, Dagomba have to present their petitions to wuna and not to Naawuni. The function of Wuna is to protect people and bring blessing. They are worshipped by pouring libation and by animal sacrifice. They include the thunder god 'Sapani' 'Tagragenti' who harass people at night and "Tiywonya' used by people to harm their enemies. "Wuni bee" is used to take care of the family in the house and it is also revealed that Nolwuni is an individual god that protects the individual in every situation. "Jebuni" is a hunter god and is used to kill bad animals in the bush. There are also nature spirits. The various sub-divisions of Dagomba have their own gods. For instance, "Mochangkweene" for Zabzugu and "Na Gbewa" for Gukpegu (Tamale). The two most powerful gods, who function throughout Dagbon are "pabo" and yender (Yendi) - (Tait, 1963).

There are many earth shrines (Tingbana) in Dagbong, including 'Jagbo', 'Sophiliga',' Guribaya' and 'Buhutikpira'. The earth custodian is 'Tindana'. Ancestors and other powers (Tiyanima-male, Tiyapagba-female) receive sacrifices from the head of the family descendants. When a sacrificed animal dies, after a struggle, and lies on its back, the ancestors have accepted it, when it, when it lies on its side it has been rejected. Ancestors are invoked, when a disaster seems likely, by pouring libation or sacrificing a fowl. They also invoke in the month of fire festival, by giving them blood and water. The soothsayers (Bagsi) reveal whichancestor should be sacrificed to, and the type of sacrifice. In such cases there are no shrines-the sacrifice may be made at any spot within the house. This again brings us to the role of the soothsayer or diviners(bagsi-plural, baga-singular). They are consulted in misfortune, to find the cause and sacrificial remedy; at birth to find which ancestor is returning.

This include; at marriage, at death, after dreams and when undertaking any new enterprise. The soothsayers have their leader in every district (Baganaa) who performs sacrifices to the ancestors. If a family is for instance affected by frequent ill-health or death the kindred head may approach the 'Baganaa' and say ,'The diviners bag (Koligu), made of animal skin has fallen on his kindred to avert continuing misfortunes(Seyire, 1968 and Tait, 1963).

\section{Religious Healing Among Dagomba}

Healing among the Dagomba stems from the way the people perceive as the cause of a particular disease. 
There is a general feeling among the Dagomba that sickness is an individual affair, as in their popular saying, "Doro n nye ko yenli" meaning, it is sickness that is an individual affair. Here, the perception is that when one is sick you are the only one who endures the pain than any other concerned person of yours. Nonetheless the Dagomba also believe that in times of disasters, plague, epidemics and the like are concerns for the whole community. Therefore, there are preventive and curative medication spreads all over the Dagon area, but the first two are typical for the general well-being of entire community. Discussion starts from there.

\section{The Healing In Bugum Festival}

The Dagomba honour their custom with an annual festival called "Bugum", meaning fire. Here, the full version of the festival is not to be narrated, but the healing aspects are duly highlighted. The celebration of the festival starts on the $9^{\text {th }}$ day of "Bugum Goli" - (Bugum month). On this day everyone (men, women and children) stays at homes. The man move around each other's home to say "Nitiyum Palli" - (Happy New Year). The significance according to the elders spoken to, of course including the researcher's biological father, who practices as a healer (mostly, for children) confirmed that the healing starts from this point of the greetings before any ritual performance. The centre point of the greetings is long life, health and prosperity. "Nawuni chaka Yuunina Kati mal nyovili ni alafee n'puhiritaba" - (God should give us long life and health to greet each other again next year". The hope is that during this period all the gods, spirits and the Supreme Being are most listening (Assimeng, 2010, p14 and five elders in yendi,northern Ghana). Later in the afternoon, households and individuals kill fowls, goat or sheep for rituals and feast. Meanwhile, dry grasses are used in preparing long torches for the festival in the night. Children who prepare torches and distribute to their grandparents, grand aunts, grand uncles, are sometimes rewarded in cash and in spirit (Tim) for protection, especially against any mishap during the night and the entire year. Significantly, after eating the evening meal, morsel of food and pieces of meat are cut and placed on the short walls (Goma) in the house. This food is said to be for the dead ancestors of the person who put it there. The food is also to be for God. The people make their vows and declarations while placing the food on the walls. They usually ask God to grant them health and long life. Finally, at outskirts of town there is a tree referred to as "bad tree" (Ti behu) where pieces of the fire from the torch are thrown. It suggests that all evils in the town are condemned, particularly witches and wizards. Fresh leaves around the bad tree are uprooted and carried home. The leaves are soaked in calabashes, pots and sometimes pans with water for drinking and bathing to prevent all kinds of ailments and epidemics for the whole year. Bugum narratives are also retrieved on $10^{\text {th }} \mathrm{July}, 2015$ from http:// www.ghanaemberline.de/en/tourism/festival,in-northerregion/index-html).

\section{The Diviner as a Healer among Dagombas}

Every community in Dagbon has a diviner (baha/bahasi) and most household also have their diviners. Various chiefs have the diviners they consult and most importantly every serious healer tries to have easy access to a diviner, if he or she (the healer) is not vested in powers of divination. Some diviners are healers as well. Bichman categorises illness in to "Illness of man" and "Illness of God"' This falls in line with the Dagomba traditions. A diviner that the researcher talked to revealed that when illness is caused by God it is easy to be solved than that one caused by man. He added that, "And it is we the seers who can tell whether it is from man or God". Dagomba in general arrogated some level of spirituality to the diviner and consult them when sickness or illness is purported to be severe in nature. The methods for divination vary from community to community and sometimes a diviner may speak to any community member about his or her illness and not necessarily for consultation with them. A diviner is capable in Dagbon of exposing the activities of witches, especially when they usually have not concluded their "killing" terms or contract with their victim. The obvious thing again is that there are categories of the diviners who are highly specialized in herbal medication. They are able to tell which herbal combination (Ti Lahi) will cure a particular disease or illness. During plague or epidemic they are consulted to advise how to go about offering healing solutions.

\section{Sacrifice to the gods for Healing}

True to E.B. Tylor's definition of religion "Belief in super-natural being" "(Assimeng, 2010, p8 and Mbiti 1969). The dagomba have many gods that they believe in. Each god is purposefully called upon to salvage the people from one problem or another. For instance, the "bugli jaabo" in Tolon is noted for its solutions to barrenness and special treatments for children. 
"Bugli" means god so "bugli jaabo" is the god of "jaabo", a snake which sometimes goes around in town unhurt. There are household shrines such as Jebuuni ,"Tillo", "wuni" and "Wumbei: The Wuni shrine is outside the house and the rest are in the room, mostly with the family heads. Sacrifices are offered to each of the gods within stipulated times. This apart, there are gods for individuals called "Noli wuni". Such individuals have spiritual attachment to the gods; make sacrifices to the Nol wuni daily, weekly, monthly and they are normally hidden in inner rooms. Nol wuni supports and protects the individual in all aspects of life to buttress the fact that healing or health is the total well-being of an individual, be it psychological, emotional, economical, spiritual, moral and so on. Economically, the god of pong Tamale is a god of rain and lightning which protects the properties of the people. In the same way, the Diari god (which is a crocodile) work against thieves and all kind of bad people.

\section{Remedy for witchcraft; the "Jinwariba" factor}

The Junworiba (singular is junwora) are a group of witch finders who operate in a state of possession. If someone has its experience he will be incited into the group. Most villages have one or Jinworba and some of them now live in towns. They are mostly women and some few men, who work in group and individual in their communities when there are persistent witchcraft activities. They are usually consulted when a community suspects the numerous deaths of their members to be the cause of witches. The jinworiba' gather themselves at outskirts of town or village to perform rituals and commence a spiritual dance in fire, some run in the fire and run out. During such times witches or wizards in those communities around would assemble and begin to confess their nefarious activities. Those people they had captured but did not kill yet could be freed and some of the witches could also be relieved of their magic possessions (So Tim). The Dabomba attribute many deaths in their communities to witches and wizards. This is evident in the witch camp at Gnaani, near Zabzugu. Shorter (1985) discusses "Exorcism" in what is close to Jinworiba. But he invariably argues that, Repeated exorcism only strengthen people's fear of witches they eradicate (Shorter, 1985, p. 195).

\section{The Healer's Prayer}

Ultimately, the majority of prayers have to do with human life in a way or the other. Many more are aimed at healing the sick and maintaining health. There are times peoples' lives are threatened with death,therefore what they need is emergency prayers, calling upon God to protect and give life (Mbiti,1974). The Dagomba believe that the departed old souls (Ancestors) are still with them. For example, my (the researcher) father calls me his father (Mba) because he believes that I took after his father. In his healing practices, I observed that any time people bring their children he will ask them "Do you believe in God?" When they answer in the affirmative, there , he tells them that it is that God will heal the child's sickness and not him. This indicates how the healers repose confidence in God. To this end, the Dagomba healing prayers are normally observed before the commencement of treatment. They are found to be speaking this common language "Tilaa be naa maa sani", meaning, the healing power is with God. There is also a ritual prayer, where any time the healers sit a fowl on "Tilahi"'( herbs gathered)they recite a lot of chanting phrases to invoke the ancestors .After that the patient will take the herbs for bathing,eating with soup and drinking. Notably, when some dosages are given they are associated with prayers (kari). Here, the ancestors are called upon especially in severe situations to intervene immediately to cure the disease or return it to where it came from. Mbiti also makes a claim that in desperation these prayers are addressed to every possible source of help as if to make absolutely sure that real or imaginary source is exhausted (Mbiti, 1974).

\section{Critical Reflections}

Although Dagombas are perceived generally to be practicing Islamic religion, many of them believe and worship additional spirits and gods. It is important to state emphatically that there are more Dagombas in villages than in cities and towns. Each village sacrifices to its individual ancestral gods and the entire society collectively worships the more powerful gods. The Dagombas also practice witchcraft and consult diviners and "Jinworiba" to rid themselves of curses and illnesses. Therefore it is difficult for even the serious Muslims to detach themselves completely from the African tradition, especially when it is about health matters. However there are many African traditional practitioners in the villages who do not have anything to do with Islam, suggesting that African traditional healing is dominant among the Dagombas. The Ghanaian Observer Newspaper on Monday, October 5,2009 gives attestation to this fact. A popular marabout in Tamale, sheikh Salawatia Husain Rashid ( Founder of Salawatia Muslim Mission of Ghana) commented about the death of Ya Na Yakubu II and opined that, " The death of Ya Na and other Dagbon chiefs is due to anger of the ancestors and the gods of the land: 
He added that, "the ancestors are restless and worried in their graves, turning and turning and this has resulted in the challenges recorded today'. (Kelvin, 2009). The hypocricy depepens when the traditional festivals like the "Damba' and 'kpini'" are almost Islamised. Anform (1986) discusses the setback of traditional medicine in Ghana, however, he points out that it is not only in healing that the traditional practitioner does, but a whole list of complains, ranging from marital problems, impotence, women in want of husband, men in want of wives, protection, childbirth and prosperity to drunkers requesting rescue (Anform, 1986,P.40). Simply put, the role of religious practice of the traditional African in Dagbon cannot be over emphasized, but the world view of the people needs stability to protect it from complete adulteration. If one visits any bonesetter's healing center in Dagbon(one at Nanton ) you will see the wonders traditional healers perform. For example,the researcher witnessed during his rounds for myself a fowl's leg been broken for treatment as a way of treating a serious bone fracture. The spirituality is that the quicker the fowl's leg heals the same way it is for the untouched patient,just to avoid the severity of the pain on the patient. What is more, Dagomba healing practices need support. The healers need education to keep them with modern trends of healing. The World Health Organization (WHO) needs to recognize the powers of the Dagbon healer and promote them worldwide. Whenever one mentioned the issue of licensing their healing practices, they never saw the need. However, there are numerous registered healers in Dagbon who still are not exposed to modern trends of practice.

\section{Conclusion}

The place of religion in the Dagomba traditional healing is formed under the world view of integration; both domestic and social activities of the people and healing techniques employed divination, sacrifices, prayers, exorcism and ritual performance to administer treatment. All societies recognize the frailness of human condition; whatever pain, illness, injury and unjustness exist, so too do the cultures and religions prescribe explanations. The illiteracy rate among the Dagomba impedes quality scientific health delivery over the years, but the complain is not so much because of the substitute of traditional healing. The financial state of the people does not in any way prevent them access to any traditional healing which is handed over to them from generation to generation. This study points out that there is adulteration of most parts of the traditions of the Dagomba, but it is evident that the "Bugum Festival', seem to be safe. When this phenomenon persists it would consequently diminish the standards of preventive healing among the people and beyond. However, the point is that, whether explanations for illness are scientific or mystical, all societies must have explanations or solutions for crises.

\section{References}

Anfom, E.E, (1986). Traditional Medicine in Ghana: Practice, Problem and Prospects. J.B Danquah Memorial Lectures. Academy of Arts and Social sciences: Accra.

A Strategic Plan for Traditional Health Care in Ghana (2000-2004) Second Draft, Ministry of Health, Ghana. August 1999.

Assimang, M.(2010). Religion and Social change in West Africa: An Introduction to the Sociology of Religion, Ghana:Woeli Publishing Services.

Awedoba, A.K \& Kuuire, S. (2010). An Ethnographic study of Northern Ghanaian Conflict: Towards a Sustainable Peace,Sub-Saharan Publishers; Retrieved 29 ${ }^{\text {th }} \quad$ June, 2015-http://www.amazon. coouk/Ethnographic- study-northernGhanaian-conflicts/dp/9988647387.

Bichma, w. (1974). 'primary Health Care and Traditional Medicine -considering the Background of changing Health care concept in Africa'.' Social sciences and Medicine 136, 175-182.

Bour, D.(2003). 'The Predominance of Distance in the Utilization of Health Services in the Kumasi Metropolis, Ghana. An International Journal on Human Geography and Environmental Sciences. GCO Journal, 56 (2), 145-157; Retrieved $27^{\text {th }}$ June, 2015http:dx:dei.org/co,1023/Ai/022452311911.

Clements, F.E.(1952). Primitive concepts of Disease. America: University of California Publications.

Edward, G. (1980). ''Role of African Traditional Healers in Mental Health Care. 'Medical Anthropology. 4/4:490-522

Ghanaian Observer Newspaper, (Monday, October, 5, 2009), '’the Death of Ya-Na,' By Kelvin Hahn, R. (1995). Sickness and Healing: An Anthropological perspective. New Haven: Yale University press.

Joyce, K. \& Thomas. A. (1982). 'The Modes of Maintaining Health in Uksambani, Kenyan'. In PS. Yoder, ed. African Health and Healing System: Proceedings of a symposium, Los Angeles: Cross Roads Press. 
Lehman, A. C \& James, E. (2001). Magic, Witchcraft, and Religion: An Anthropological Study of the supernatural. California: GC Graw companies.

Louser, P. (2004) Unpacking the Expression, 'Indigenous knowledge Systems'. Indilinga:

African Journal of Indigenous Knowledge Systems. 4(1):74-88.

Mahama, I. (2003). Conflicts in Northern Ghana, Tamale: Cerber System.

Mahama, I. (2004) History and Traditions of Dagbon, Tamale: GILLBT

Mascie, T. (1993) The Anthropology of Disease, Newyork: Oxford University Press.

Mbiti J. S. (1969). African Religions and Philosophy, Oxford: Heinemann.

Mbiti J. S. (1974). Prayers of African Religion, London: SPC.

Seyire, A. (1968). Yendi Project Report, Report 9, IAS, Legon

Shorter, A. (1985) Jesus and the Witchdoctor: An Approach to Healing and Wholeness. London: Geoffrey Chapman.

Weiman, A. and Sun L. (1974) Why Do Indigenous Healers successful. Heal Social Science Med.

Part B; Med. Anthropology, 13: 7-26.

WHO (2001) Legal Status of Traditional Medicine and Complementary Attentive Medicine. Geneva: IAS

WHO (2002) WHO Policy Perspective on Medicines- Traditional Medicine, Growing Needs and Potentials. Geneva: IAS

Yoder, P. S. (1982) Issues in the Study of Ethnomedical Systems in Africa. Ed. African Health and Healing Systems, Los Angeles: University of California Press 